\title{
Peningkatan Literasi Cerita Wayang sebagai Upaya Pemertahanan Nilai-Nilai Budaya Lokal
}

\author{
Alfiah \\ Universitas PGRI Semarang \\ alfi_hasna@yahoo.co.id
}

\begin{abstract}
Abstrak
Wayang merupakan salah satu wahana atau alat pendidikan watak yang efektif, karena wayang mengajarkan ajaran dan nilai tidak secara dogmatis dan teoritis sebagai indoktrinasi, tetapi secara demokrasi dan konkrit dengan menghadirkan kehidupan tokohtokoh sebagai teladan yang nyata. Melalui ajaran moral yang berupa ungkapan nilai-nilai keluhuran bagi manusia secara lahir dan batin yang termuat di dalam cerita wayang, dapat dijadikan sebagai teladan hidup guna membina sifat manusia secara berketuhanan, pribadi, dan sosial. Ironisnya, muatan nilai-nilai luhur dalam cerita wayang tersebut belum mampu tercerna secara optimal oleh masyarakat, khususnya generasi muda karena pada umumnya mereka kurang menguasai bahasa Jawa. Keterbatasan dalam pemahaman penggunaan bahasa Jawa menjadi kendala utama dalam pemahaman isi cerita wayang.

Berdasarkan fenomena yang cukup memprihatinkan tersebut, mendorong munculnya berbagai upaya untuk menjembatani pemertahanan nilai-nilai budaya lokal dalam bentuk cerita wayang sebagai alternatif media pendidikan karakter pada generasi muda dalam menghadapi bebasnya arus informasi sebagai dampak dari MEA. Dalam hal ini, peningkatan literasi cerita wayang menjadi konsentrasi yang perlu diberdayakan. Adapun upaya peningkatan literasi tersebut dapat dilakukan melalui berbagai cara, antara lain: 1) penyediaan buku cerita wayang yang komunikatif dan inovatif bagi anak usia dini; 2) penerapan metode dan media pembelajaran yang kreatif dan inovatif dalam pembelajaran bahasa Jawa di sekolah; 4) penugasan siswa untuk menonton pertunjukan wayang secara rutin oleh guru bahasa Jawa . Melalui upaya tersebut diharapkan cerita wayang dapat tercerna secara optimal sehingga generasi muda mampu memahami dan meneladani nilai-nilai luhur yang tersirat di dalamnya.
\end{abstract}

Kata kunci: literasi, cerita wayang, nilai-nilai budaya lokal

\begin{abstract}
Wayang is an effective means of character teaching because it teaches tenets and values, taught not in dogmatic and theoretical ways as an indoctrination, but in democratic and concrete ways that presents real figures as a model. Through moral teaching in the form of noble expressions of human in physical and spiritual contexts that exist in wayang, they can be applied as a life model figure to guide humans' characters in personal and social life as a whole. Ironically, the content of nobleness that is available in wayang is still incapable to be comprehended by society, especially for teenagers where it happens because they are lack of Javanese mastery. Limitations in comprehending and communicating using Javanese create an ultimate barrier in understanding the story of wayang.
\end{abstract}


Based on the phenomenon, there should be an attempt to bridge the maintenance of the local wisdom as an alternative media for character education that is dedicated to young generation in facing the freedom of information flows as the effect of AseanEconomy Community (MasyarakatEkonomiAsean (MEA)). In regards to the situation, the improvement of wayang story literacy becomes a focus that needs to be empowered. The attempt to enhance the literacy can be carried on in some ways: 1) the provision of communicative and innovative wayang book for early childhood; 2) the application of creative and innovative learnings as well as the method and the media in Javanese learning in school; 4) Assigning students to watch wayang as a routine, given by Javanese teachers. By applying the attempts, it is expected that wayang story can be comprehended as a whole so that the young generation is able to comprehend and adopt the story as a model in implementing the values available in the story.

Keywords: literacy, wayang story, local wisdom value

\section{PENDAHULUAN}

Wayang merupakan salah satu unsur kebudayaan yang diciptakan oleh manusia. Walaupun demikian, wayang dapat membentuk kepribadian manusia, khususnya bagi penggemarnya, karena dipandang mengandung nilai-nilai luhur ( Albiladiyah, 2014) Dalam bahasa Jawa, kata wayang berarti "bayangan". Jika ditinjau dari arti filsafatnya "wayang" dapat diartikan sebagai bayangan atau merupakan pencerminan dari sifat-sifat yang ada dalam jiwa manusia, seperti angkara murka, kebajikan, serakah dan lain-lain Cerita wayang juga merupakan salah satu jenis sastra tradisional yang masih popular dan memasyarakat hingga kini. Cerita wayang disebut sebagai sastra atau cerita tradisional karena telah amat lama menjadi milik bangsa dan mewaris secara turun-temurun kepada tiap generasi terutama secara lisan khususnya pada masyarakat Jawa (http://definisidanpengertian.blogspot.co.id/2011)..

Dipaparkan pula oleh Amir dalam Junaedi (2015) bahwa wayang juga sering disebut sebagai salah satu wahana atau alat pendidikan watak yang efektif, karena wayang mengajarkan ajaran dan nilai tidak secara dogmatis dan teoritis sebagai indoktrinasi, tetapi secara demokrasi dan konkrit dengan menghadirkan kehidupan tokoh-tokoh sebagai teladan yang nyata. Melalui ajaran moral yang berupa ungkapan nilai-nilai keluhuran bagi manusia secara lahir dan batin yang termuat di dalam cerita wayang, dapat dijadikan sebagai teladan hidup guna membina sifat manusia secara berketuhanan, pribadi, dan sosial.

Sejalan dengan konsep tentang dunia pewayangan, Sulistyobudi (2014) memaparkan bahwa seni pewayangan sebagai bagian dari budaya Jawa memiliki relevansi dengan 'jatidiri bangsa'. Seni pewayangan diposisiskan sebagai salah satu jatidiri bangsa yang perlu mendapatkan perhatian yang kontinyu untuk kelestarian dalam menghadapi tantangan kehidupan dan perkembangannya.

Meskipun wayang disebut sebagai cerita tradisional yang memasyakat hingga masa modern ini dan memuat ajaran moral yang berupa ungkapan nilai-nilai luhur dan jatidiri bangsa, akan tetapi pemahaman terhadap cerita tersebut masih dirasa sulit. Selain itu, cerita wayang sebagai salah satu warisan budaya lokal yang telah mendunia dan mengandung berbagai ajaran atau nilai-nilai karakter, belum mampu terserap dengan baik, khususnya oleh generasi muda di era sekarang ini. Hal ini disebabkan karena bahasa pengantar cerita wayang adalah bahasa Jawa, yakni bahasa ibu masyarakat Jawa khususnya Jawa Tengah dan Jawa Timur. Bahasa Jawa tersebut belum secara optimal dikuasai oleh seluruh lapisan masyarakat pemakainya. Kenyataan yang cukup memprihatinkan tersebut menjadi salah satu kendala dalam pemahaman isi cerita 
wayang. Oleh karena itu, cerita wayang yang sarat akan ajaran-ajaran moral tersebut belum mampu terserap secara optimal oleh sebagian besar masayarakat Jawa di era modern ini. Jika kondisi yang demikian tersebut tidak segera teratasi, masyarakat Jawa akan kehilangan salah satu media potensial dalam pembelajaran karakter terhadap generasi penerus bangsa. Sementara banyak wacana yang menyatakan bahwa wayang dapat dikatakan sebagai wahana atau alat pendidikan yang efektif karena wayang mengajarkan ajaran dan nilai-nilai secara demokrasi dan konkrit melalui kehadiran tokoh-tokoh sebagai teladan yang nyata. Bahkan sebagai media pendidikan karakter, wayang berisi ajaran moral berupa ungkapan nilai-nilai keluhuran secara lahir dan batin, yang pantas dijadikan teladan hidup guna membina sifat manausia secara berketuhanan, pribadi, dan sosial (Junaidi, 2015). Dengan demikian, berbagai upaya dalam peningkatan literasi wayang bagi generasi penerus di era modern ini perlu sekali diberdayakan, sekaligus sebagai upaya pemertahan budaya lokal.

Bertolak dari kondisi nyata seperti uraian di atas, dunia pendidikan menjadi salah satu alternatif tempat yang dipandang efektif untuk mendesain berbagai pola literasi cerita wayang baik secara formal mapun informal. Dalam hal ini, pengajaran literasi menajdi pilihan yang bijak karena hanya melalui dunia pendidikanlah pengajaran literasi dapat ditanamkan pada siswa. Pendidikan merupakan ujung tombak kemajuan literasi. Seperti yang dipaparkan dalam Buku Sumber untuk Dosen LPTK dalam Pembelajaran Literasi di Sekolah Menengah Pertama, bahwa kemamapuan siswa dalam berliterasi merupakan langkah awal dalam mencapai keberhasilan pembelajaran. Salah satu indikator keberhasilan pembelajaran ditandai dengan semakin baiknya tingkat literasi siswa. Artinya, semakin baik tingkat literasi siswa semakin baik pula tingkat daya serap siswa terhadap informasi yang diperolehnya dalam proses pembelajaran.

Sejalan dengan konsep di atas, Klein dkk (dalam asropah dkk, 2014) memberikan penjelasan yang lebih komprehensif mengenai definisi literasi dengan memberikan beberapa penanda seseorang memiliki kemampuan literasi, antara lain: a) kemampuan membaca makna tersurat; b) kemampuan berbicara secara jelas, tepat, dan logis; c) kemampuan menulis dengan mudah dan nyaman; d) kemampuan mengomunikasikan ide-ide pokok melalui tulisan; e) kemampuan memahami pesan lisan, baik secara eksplisit maupun implisit; dan f) kemampuan menemukan kepuasan, tujuan dan pencapaian melalaui berbagai tindak literasi. Dalam penjelasan lebih lanjut, bahwa melihat keterkaitan antara kemampuan membaca dan menulis yang seperti dua sisi mata uang. Seseorang yang dapat menulis dengan baik cenderung memiliki kemampuan membaca yang baik. Begitu juga sebaliknya, seseorang yang memiliki kemampuan membaca yang baik memiliki kecenderungan untuk menjadi penulis yang baik. Dalam hal ini, Arshad (2008) memaparkan pula bahwa definisi literasi secara komprehensif tersebut mengarah pada lierasi kemampuan mendengar, bertutur, membaca, dan berfikir dalam suatu bahasa.

Literasi juga dipandang sebagai praktik kultural yang berkaitan dengan persoalan sosial dan politik. Oleh karenanya para pakar pendidikan dunia berpaling kepada definisi baru tentang literasi. Selain itu, dewasa ini kata literasi banyak disandingkan dengan kata-kata lain, misalnya literasi komputer, literasi virtual, literasi matematika dan sebagainya. Hal tersebut merupakan transformasi makna literasi karena perkembangan zaman. Oleh sebab itu, Freebody dan Luke menawarkan model literasi sebagai berikut:

1. Memahami konteks dalam teks: mengenali dan menggunakan fitur seperti alfabet, suara, ejaan, konvensi dan pola teks.

2. Terlibat dalam memaknai teks: memahami dan menyusun teks tertulis dan teks virtual dan lisan yang berati dari budaya tertentu, lembaga, keluarga, masyarakat, negara-negara dan lain-lain. Menggambarkan skema yang ada. 
3. Menggunakan teks secara fungsional.

4. Melakukan analisis dan mentransformasikan teks secara kritis: memahami dan bertindak atas pengetahuan bahwa teks-teks tidak netral. Teks mewakili pandangan tertentu, diam, mempengaruhi ide-ide orang. Desain teks dan wacana dapat dikritik dan didesain ulang dengan cara baru dan hibrida.

Berikut adalah tujuh prinsip yang harus diterapkan dalam pendidikan bahasa berbasis literasi:

1. Literasi adalah kemampuan hidup (life skill).

2. Literasi mencakup kemampuan reseptif dan produktif dalam upaya berwacana.

3. Literasi adalah kemampuan memecahkan masalah.

4. Literasi adalah refleksi penguasaan dan apresiasi budaya.

5. Literasi adalah kegiatan refleksi (diri).

6. Literasi adalah kolaborasi.

7. Literasi adalah kegiatan melakukan interpretasi

(http://prianganaulia.blogspot.com/2014/02/transformasi-makna-literasi.html)

Berdasarkan latar belakang kondisi di atas, tujuan dalam penulisan artikel ini adalah memaparkan bagaimana upaya peningkatan literasi cerita wayang bagi generasi penerus bangsa, khususnya peserta didik dalam rangka pemertahanan budaya lokal.

\section{UPAYA PENINGKATAN LITERASI CERITA WAYANG}

Seperti yang telah dipaparkan di atas, bahwa tingkat literasi dapat menetukan pula tingkat kemampuan seseorang dalam memahami atau menyerap informasi yang diterimanya. Dalam hal ini, cerita wayang yang selama ini disebut-sebut sebagai warisan budaya yang sarat akan nilainilai moral perlu sekali dipahamkan kepada seluruh lapisan masyarakat, khususnya masayarakat Jawa. Mengapa cerita wayanag perlu diajarkan, karena wayang merupakan bagian dari khasanah kebudayaan yang harus dipelihara dengan baik, meskipun telah terjadi berbagai perubahan yakni dengan munculnya berbagai kreasi dalam dunia pewayangan. Namun kenyataannya secara esensial nilai-nilai budaya yang terkandung di dalamanya masih mengakar kuat pada masyarakat pendukunya (Hadiprayitno, 2009). Dalam paparannya lebih laanjut, dijelaskan pula bahwa dalam wayang penuh dengan simbol-simbol, perilaku kemasyarakatan diangkat dan dikemas sebagai wahana tontonan dan hiburan yang menarik bagi banyak orang. Dengan demikian, cerita wayang tidak cukup hanya dinikmati oleh sebagian besar orang tua, khususnya para kesepuhan yang menggemari cerita tersebut. Akan tetapi, para generasi muda pun perlu sekali belajar untuk memahmi cerita wayang tersebut dengan tujuan dapat mencerna isi ceritanya dan meneladani nilai-nilai ajaran moral yang tersirat di dalam cerita wayang. Oleh karena itu, sejalan dengan pentingnya belajar tentang wayang, dalam artikel ini penulis mencoba memaparkan berbagai upaya peningkatan literasi cerita wayang yang dapat dilakukan melalui berbagai cara, antara lain: 1) penyediaan buku cerita wayang yang komunikatif dan inovatif bagi anak usia dini; 2) penerapan metode dan media pembelajaran yang kreatif dan inovatif dalam pembelajaran bahasa Jawa di sekolah; 4) penugasan siswa untuk menonton pertunjukan wayang secara rutin oleh guru bahasa Jawa. Penjelasan lebih lengkap dari masing-masing upaya tersebut di atas, adalah sebagai berikut.

Pertama, penyediaan buku cerita wayang ramah anak yang komunikatif dan inovatif bagi anak usia dini perlu sekali diupayakan. Pada saat anak usia dini atau berumur antara 0-6 tahun, otak berkembang sangat cepat hingga 80 persen. Pada usia tersebut otak menerima dan menyerap berbagai macam informasi, tidak melihat baik dan buruk. Itulah masa-masa yang dimana 
perkembangan fisik, mental maupun spiritual anak akan mulai terbentuk. Karena itu, banyak yang menyebut masa tersebut sebagai masa-masa emas anak (Golden Age). Dalam masa seperti ini, yakni anak memiliki potensi yang kuat untuk belajar, kita sebagai orang tua hendaknya memanfaatkan masa emas anak untuk memberikan pendidikan karakter yang baik bagi anak. Sehingga anak bisa meraih keberhasilan dan kesuksesan dalam kehidupannya di masa mendatang (Wibowo, 2011). Oleh karena itu, tidak ada salahnya jika sejak dini anak sudah mulai dikenalkan dan diperdengarkan dengan cerita wayang. Tentu saja anak akan sejak dini pula belajar mengenal nama-nama tokoh sampai dengan karakter dari masing-masing tokoh.

Mengingat potensi anak yang belum bisa membaca maka anak akan dapat menangkap berbagai informasi melalui apa yang mereka dengar atau dilihat. Meskipun dalam perkembangan sekarang ini, cerita wayang sudah dikemas secara kreatif dalam bentuk film yang cukup menarik perhatian anak-anak, akan tetapi pengadaan buku cerita wayang yang ramah anak perlu juga diupayakan. Buku cerita yang dimaksud adalah buku cerita yang komunikatif untuk anak usia dini, artinya cukup menggunakan bahasa yang sederhana, singkat, dan padat, serta inovatif, artinya buku disajikan dengan sangat menarik, dilengkapi dengan gambar-gambar berwarna yang ilustratif, dan tidak terlalu tebal sehingga akan membantu mempermudah anak dalam mengikuti isi ceritanya. Melalui tampilan gambar yang cukup dominan, akan mampu merangsang anak untuk mengingat dan jika diulang-ulang anak akan bias hafal. Dengan buku akan bernilai lebih praktis dan efektif karena buku bisa dibawa kemana-mana dan bisa dibaca oleh siapa pun tidak membutuhkan alat bantu yang lain. Selain itu, dengan buku cerita sekaligus dapat digunakan dalam pembelajaran membaca. Dalam hal ini, kuantitas muatan isi cerita tidak begitu diutamakan, karena lebih mengutamakan pada proses pengenalan nama-nama tokoh dan karakter dari masing-masing tokoh. Jika anak sejak dini sudah berbekal yang demikian, nanti sampai waktunya mereka belajar dibangku kelas yang lebih tinggi, Sekolah Dasar (SD), Sekolah Menengah Pertama (SMP), atau pun Sekolah Menengah Atas (SMA) tidak akan merasa asing dengan cerita wayang. Paling tidak anak sudah mengenal nama-nama tokoh cerita wayang dengan karakter-karakternya. Begitu anak mengenal nama dan karakter tokohnya, biasanya anak dapat memilih salah satu tokoh yang diidolakan. Dengan demikian, secara tidak langsung anaka sudah mampu membedakan mana tokoh yang bersifat baik dan mana yang tidak baik. Oleh karena itu, muatan nilai-nilai moral, pendidikan dalam cerita wayang akan mampu terserap oleh anak sejak kecil. Anak tidak akan terbebani oleh rumitnya pemahaman bahasa Jawa dalam tingkatan ragamnya.

Kedua, penerapan metode dan media pembelajaran yang kreatif dan inovatif dalam pembelajaran bahasa Jawa di sekolah juga sangat penting. Yang terpenting dalam pembelajaran bahasa Jawa bukan substansi materi tetapi justru kebahasaan atau kesastraan secara teoritis saja, tetapi justru pembelajaran karakter melalui filosofi budaya Jawa itulah yang diutamakan. Oleh karena itu, dalam proses pembelajaran bahasa Jawa, guru harus mampu memfasilitasi siswa dengan pola pembelajaran yang menarik, kreatif, dan inovatif. Artinya, guru mampu memberdayakan pengalaman belajar siswa di kelas, yang lebih bermakna. Siswa dilibatkan secara aktif dalam proses pembelajaran, tidak hanya menyimak apa yang disampaikan oleh guru. Keterlibatan siswa secara aktif tersebut akan mampu memperkuat pemahamannya terhadap materi yang dipelajarinya. Sebagai contoh: 1) dalam mempelajarai cerita wayang, siswa diminta untuk bermain peran memerankan lakon wayang secara kelompok. Dalam proses ini, siswa tidak hanya terbatas memahami teks bacaanya tetapi berusaha memvisualisasikan isi lakon cerita wayang secara maksimal dengan cara yang dikuasainya. Jika siswa sudah mampu memerankannya, sudah tentu siswa tersebut telah mampu memahami isi cerita wayang dengan 
baik; 2) guru menugasi siswa untuk mencari sumber cerita wayang, kemudian membacanya, dan melaporkan progres hasil bacaanya.

Ketiga, upaya lain yang diharapkan dapat meningkatkan literasi cerita wayang adalah menugasi siswa menonton pertunjukan wayang secara langsung dan dilakukan secara rutin. Melalui cara ini siswa akan memperoleh pengalaman secara langsung terkait dengan tampilan nilai-nilai seni cukup menarik melalui perpaduan suara gamelan, iringan tembang, dan kepiawaian dalang dalam memainkan tokoh-tokoh wayang. Seperti yang dipaparkan oleh Sulistyobudi (2014), bahwa dalam pertunjukan wayang memiliki garap pakeliran pertunjukan wayang kulit. meliputi sabet (semua gerak wayang meliputi: tanceban, entas-entasan, ulap-ulap, cancut), catur (bahasa dalang yang digunakan dalam pertunjukan wayang meliputi: janturan, pocapan dan ginem) dan iringan atau karawitan pedalangan meliputi: sulukan, dodogan,keprakan dan instrument gamelan digarap atau diolah semenarik mungkin dengan halhal yang baru sekiranya mempunyai daya tarik tinggi dan tetap bernilai. Dengan menyaksikan pertunjukan secara langsung, diharapkan siswa dapata terinspirasi mempelajari lebih dalam sehingga muncul keingintahuan yang lebih serius terkait dengan cerita wayang.

\section{KESIMPULAN}

Cerita wayang merupakan warisan budaya yang memuat nilai-nilai filosofi budaya yang adi luhung. Meskipun demikian cerita wayang belum terpahami oleh seluruh lapisan masyarakat secara mendalam, khususnya para generasi muda. Oleh karena itu, upaya-upaya mentransformasi nilai-nilai budaya wayang kepada generasi muda harus terus digalakkan. Cerita wayang tidak cukup hanya digelar melalui pertunjukan wayang kulit saja, tetapi juga perlu disalurkan melalui berbagai bentuk media. Seperti yang telah dipaparkan di atas, bahwa dalam upaya peningkatan literasi cerita wayang, terdapat tiga cara yang memungkinkan untuk dikembangkan. Tiga cara tersebut, antara lain: 1) mnyediakan buku cerita wayang ramah yang komunikatif, kreatif, dan inovatif; 2) menciptakan pola pembelajaran bahasa Jawa di kelas yang aktif, kreatif, dan inovaatif; 3) menugasi siswa untuk menonton pertunjukan wayang secara langsung yang dilaksanakan secara rutin, minimal satu kali dalam satu bulan. Tiga cara tersebut diupayakan dengan tujuan agar nilai-nilai filosofi budaya Jawa yang adi luhung idak akan terkikis oleh pesatnya arus globalisasi.Maka peneladanan nilai-nilai karakter dalam cerita wayang perlu disosialisasikan dan dipahamkan kepada seluruh lapisan masyarakat, terutama para generasi muda.

\section{DAFTAR PUSTAKA}

Asropah, dkk. 2014. Proseding:"Tingkat Literasi Bahasa Jawa Siswa SMP Negeri Kota Semarang".

Hadiprayitno, Ki Kasidi. 2009. Jantra, Vol. IV, No. 7 "Perlunya Belajar Wayang dalam Kehidupan Budaya Jawa."

Junaidi. 2015. Makalah Sanggar Wayang Walisanga Yogyakarta. "Wayangan sebagai Media Pndidikan Karakter Bangsa.

Nurgiyantoro, Burhan. 2011. Jurnal Vol. 01, No.01. "Pendidikan Karakter."

Sulistyobudi Noor. 2014. Jantra Vol. 9, No. 2."Budaya Wayang:Kelestariannya dan Tantangan ke Depan".

Sunjoyo, Suparmin. 2015. Makalah Seminar Nasional Wayang Indonesia (Semar Wangi) "Membangun Karakter Bangsa Melalui Pertunjukan Wayang." 
https://ekodariyanto.wordpress.com/2012/03/20/nilai-nilai-pendidikan-dalam-kebudayaanwayang

isyf.or.id/2015/12/07) meneladani-karakter-wayang.

http://definisidanpengertian.blogspot.co.id/2011/02/pengertian-wayang.html

http://aninditawikanti.blogspot.co.id/2013/01/mengenal-wayang-lebih-jauh-pengertian.html.

http://prianganaulia.blogspot.com/2014/02/transformasi-makna-literasi.html

https://ekodariyanto.wordpress.com/2012/03/20/nilai-nilai-pendidikan-dalam-

kebudayaan-wayang. 